\title{
Serine/Threonine-Protein Kinase Chk1
}

National Cancer Institute

\section{Source}

National Cancer Institute. Serine/Threonine-Protein Kinase Chk1. NCI Thesaurus. Code C25919.

Serine/threonine-protein kinase Chk1 (476 aa, $~ 54 \mathrm{kDa}$ ) is encoded by the human CHEK1 gene. This protein is involved in both DNA damage response and cell cycle regulation. 